\title{
Is there any benefit of harmonic scalpel for hemorrhoidectomy versus conventional diathermy?
}

\author{
Geleneksel diyatermi ile kıyaslandığında harmonik bistürinin hemoroidektomide faydası var mıdır?
}

Doğan Yıldırım ${ }^{1}$, Turgut Dönmez ${ }^{2}$, Okan Murat Aktürk ${ }^{1}$, Ahmet Kocakuşak ${ }^{1}$, Mikail Çakır ${ }^{1}$, Mustafa Ertuğrul Yurtteri ${ }^{1}$

\section{Abstract}

Aim: Symptomatic hemorrhoidal disease is among the most common surgical diseases and it may necessitate surgical intervention. The most common and effective approaches used for surgical treatment are harmonic scalpel hemorrhoidectomy and conventional diathermy excision. The aim of the study was to compare the outcomes of hemorrhoidectomy using harmonic scalpel and the conventional diathermy excision techniques. Methods: The files of 113 consecutively operated patients ( 26 females $23 \%, 87$ males $77 \%$ ), who were operated on for symptomatic Grade III-IV hemorrhoids, were retrospectively reviewed for length of operation and hospitalization, early and delayed bleeding, urinary retention, postoperative abscess and anal stenosis. Exclusion criteria were additional operations, recurrent cases and inflammatory bowel disease.

Results: Conventional diathermy hemorrhoidectomy in 60 (53\%) and harmonic scalpel hemorrhoidectomy were used in 53 patients (47\%). There were significant differences between the operation and hospitalization times in favor of harmonic scalpel group $(\mathrm{p}<0.05$ for both). The other parameters did not show any significant differences ( $p>0.05$ for all).

Conclusion: Harmonic scalpel hemorrhoidectomy is advantageous and superior to conventional diathermy hemorrhoidectomy in regard to shorter operation time and earlier discharge from the hospital with no additona complications.

Keywords: Harmonic, Hemorrhoidectomy, Scalpel, Surgery, Technique

Öz

Amaç: Semptomatik hemoroidal hastalık, en yaygın cerrahi hastalıklar arasındadır ve tedavide cerrahi müdahale gerekebilir. Cerrahi tedavide etkili yaklaşımlar harmonik bistüri ile hemoroidektomi ve konvansiyonel diyatermi ile eksizyondur. Çalışmanın amacı, harmonik bistüri ve konvansiyonel diyatermi eksizyon teknikleriyle yapılan hemoroidektomi sonuçlarını karşılaşıımaktı.

Yöntemler: Semptomatik Evre III-IV hemoroid nedeniyle ardışık operasyon yapılan 113 hasta (26 kadın, \% 23; 87 erkek, \% 77) dosyaları retrospektif olarak incelendi ve operasyon ve hastanede kalıs süresi, erken ve gecikmiş kanama, idrar yapmada zorluk, postoperatif apse ve anal stenoz araştırıldı. Dışlama kriterleri; ek cerrahi uygulanması, rekürren vakalar ve inflamatuvar bağırsak hastalığı idi.

Bulgular: Altmış hastada (\%53) konvansiyonel diyatermi ile hemoroidektomi ve 53 hastada (\%47) harmonik bistüri ile hemoroidektomi uygulandı. Operasyon ve yatış süreleri arasında harmonik bistüri grubu lehine anlamlı farklılık tespit edildi (her ikisi için $\mathrm{p}<0,05$ ). Diğer parametrelerde anlamlı bir farklılık yoktu (hepsi için $\mathrm{p}>0,05)$.

Sonuç: Harmonik bistüri ile hemoroidektomi, ameliyat süresinin kısa olması ve hastaneden daha erken taburcu olmasına karşın ek bir komplikasyona rastlanmadığı için konvansiyonel diyatermi hemoroidektomisine göre avantajlidır.

Anahtar Kelimeler: Harmonik, Hemoroidektomi, Bistüri, Cerrahi, Teknik
${ }^{1}$ Department of General Surgery, Ministry of Health Haseki Teaching and Research State Hospital, University of Health Sciences, Istanbul, Turkey

${ }^{2}$ Department of General Surgery, Ministry of Health Lutfiye Nuri Burat State Hospital, Istanbul, Turkey

Ethics Committee Approval: The study was approved by the local ethics authority (21.07.2017/519).

Etik Kurul Onayı: Çalışma, lokal etik kurul tarafindan onaylanmıştır (21.01.2017/519)

Conflict of Interest: No conflict of interest was declared by the authors. Çıkar Çatışması: Yazarlar çıkar çatışması bildirmemişlerdir.

Financial Disclosure: The authors declared that this case has received no financial support. Finansal Destek: Yazarlar bu olgu için finansal destek almadıklarını beyan etmişlerdir.

Geliș Tarihi / Received: 28.01.2018

Kabul Tarihi / Accepted: 28.02.2018

Yayın Tarihi / Published: 02.03.2018

Sorumlu yazar / Corresponding author Ahmet Kocakuşak

Adres/Address: Sağlık Bilimleri Üniversitesi, Haseki Eğitim ve Araştırma Hastanesi, Genel Cerrahi Kliniği, İstanbul, Türkiye

Tel: +905324484805

e-posta: ahmetkocakusak@yahoo.com

Copyright (C) ACEM 


\section{Introduction}

Hemorrhoids are one of the most common anorectal disorders affecting around $39-45 \%$ of the Western population $[1,2]$. The most common symptoms are bleeding, swelling, prolapse, and peri-anal irritation. They may be further complicated with thrombosis which sometimes causes severe pain. The current theory about symptomatic hemorrhoids is the destruction of the anal cushions, which help the defecation and fine-tuning of anal continence. The muscle fibers are then replaced by collagen and there is an inflammatory process in the connective tissues around vessels which leads to ischemia and ulceration thus ending up in bleeding [3]. Hence the disease is very common and causes a significant number of operations and creates a community burden. For example, there are over 20000 hemorrhoidal procedures in the United Kingdom each year [4].

The ideal operation for hemorrhoids must have low recurrence, low postoperative pain causing less hospital stay, early return to work and minimum morbidity. The main and ultimate treatment for advanced stage hemorrhoidal diease is hemorrhoidectomy. Various methods of hemorrhoidectomy have been introduced to decrease pain, bleeding, stenosis, and chronic postoperative itchy discharge.

Conventional hemorrhoidectomy is carried out by creating an anodermal wound after the excision of the hemorrhoidal packages and is associated with significant pain, marked bleeding, and a prolonged period before return to normal activity [5]. The ultrasonic scalpel uses ultrasonic vibration to cut tissue and automatically coagulate at the same time by generating heat. A hemorrhoidectomy performed with an ultrasonic scalpel may have several advantages, including less damage to tissues, better hemostasis, less stimulation to neuro $\neg$ muscular tissues, and local control of the surgical site, compared to a hemorrhoidectomy performed with surgical scissors and/or mo $\neg$ nopolar electric cautery [6].

In the present retrospective clinical study, we aimed to assess the pain and complication rates following the use of either the traditional conventional hemorroidectomy procedure or harmonic scalpel hemorrhoidectomy.

\section{Material and methods}

The present retrospective study was done at the Department of Surgery, Haseki Training and Research State Hospital, University of Health Sciences between June 2014 and May 2017. Approval of the local ethic committee was obtained. All procedures were in accordance with the ethical standards of the responsible committee on human experimentation and with the Helsinki Declaration of 1964 and later versions.

A total of 113 patients were included in the study. All patients were aged between 18 and 80 of both genders. The patients represented mostly with rectal bleeding, mucous discharge, pain and itching to the hospital. The diagnosis was made by rectal examination and medical treatment was given initially. If medical treatment failed or the patient did not want to continue medical therapy, the patients with symptomatic 3rd or 4th grade of the hemorrhoids were referred to surgery. All patients had signed written informed consent. Patients who had gone under harmonic scalpel hemorrhoidectomy (HS Group) and conventional hemorroidectomy ( $\mathrm{CH}$ Group) were selected for a retrospective study.

Patients who were going under additional operations like fissure or fistulae, or who have inflammatory bowel diseases were excluded. The patients who had previous hemorrhoidal operations were also excluded. Anticoagulant medication or aspirin were told to stop 7 days prior to surgery and replaced by low molecular weight heparin.
A standardized spinal anesthesia was the preferred method. Previous spinal surgery and patients' choice were indications for general anesthesia. Both procedures were carried out in the surgery room with the patient in the lithotomy position and with Trendelenburg position. Each patient was examined under anesthesia. The hemorrhoidal package was held by two forceps at the apex and the mucocutaneous junction.

In the harmonic scalpel group (HS Group), the package was held with a forceps from the apex and the junction. Then, the harmonic instrument (Harmonic $\AA$; Ethicon Inc., Cincinnati, $\mathrm{OH}$, USA) was applied with the jaws facing on the pedicle. No securing sutures were applied in the harmonic scalpel group and no mucosa suturing was used unless necessary.

An incision was made at the base of the package and the tissue was separated from the internal sphincter either by diathermy and/or scissors in the conventional group ( $\mathrm{CH}$ Group). Then, the hemorrhoidal pedicle was transfixed with no 0 absorbable continuous sutures. The wounds were left open. An anal sponge was left into the anal canal at the end of the procedure after inspection by an Eisenhammer retractor.

Both groups had anal canal packing to secure homeostasis. The patients' files were reviewed for demographic data including age, gender, weight in kilograms and height in meters, operation time, length of hospitalization, pain scoring, the usage of additional analgesics and complications. BMI was calculated as weight in kilograms divided by the square of height in meters $(\mathrm{kg} / \mathrm{m} 2)$. The pain scoring was carried out by a simple questionnaire and patients were asked to score their pain according a scale ranging from $0-5$, indicating 0 as no pain, and 5 as the worst pain encountered. The size or number of removed packages or the size of excised packages were not recorded due to contraction because of variations due to the time past until pathological examination and also hemorrhoidal packages removed with diathermy may have undergone additional shrinkage because of the destructive effect of heat.

All patients were given a standard scheme of analgesics as intravenous paracetamol (Perfalgan, $10 \mathrm{mg} / \mathrm{ml}$, intravenous, $100 \mathrm{ml}$ vial, Bristol-Myers Squibb, Istanbul, Turkey) in three doses with eight hours interval; the first dose was given in the operation room while the operation ended. The patients were applied one additional dose of $20 \mathrm{mg}$ tenoxicam (Tilcotil, $20 \mathrm{mg}$, intravenous, $1 \mathrm{ml}$ vial, Deva, Istanbul, Turkey) intravenously, if needed. If the pain persisted, slow intravenous use of tradamol $50 \mathrm{mg}$ (Contramal, $50 \mathrm{mg} / \mathrm{ml}$, intravenous $2 \mathrm{ml}$ ampoule, Abdi Ibrahim, Istanbul, Turkey) was the preferred way for pain control. The need was decided on the patients' pain statement. The patients were also asked to evaluate and score their pain on the other day of the surgery.

The patients were asked to evaluate and score their pain on the other day of the surgery.

The patients were discharged on the first postoperative day unless there are other clinical indications. All patients were advised to use siz bath and proper diet and a standard medical treatment. They were examined on the first postoperative day and within one week after the surgery. We used the files of the outpatient polyclinic since we followed up the patients at least for six months in addition to communicating them by phone.

Statistical analysis was done with SPSS software. Student t-test was applied to compare the hospitalization and operation times between the groups. The differences were considered statistically significant if the $\mathrm{p}$ value was equal to or less than 0.05 .

\section{Results}

The files of 113 (26 females 23\%, 87 males $77 \%$ ) consecutive patients were reviewed. While 60 patients $(53 \%)$ 
underwent conventional hemorrhoidectomy $(\mathrm{CH})$ either with cold knife or diathermy depending on the surgeons' decision (CH Group), 53 patients (47\%) underwent harmonic scalpel (HS) excision (HS Group). Patients' ages were between 18 and 80 years. The average age was $45.4 \pm 12.1$ years. There was no difference between the groups in terms of age, gender and body mass index (Table 1). One hundred and five patients $(92.1 \%)$ underwent spinal anesthesia as eight $(7.1 \%)$ patients were operated under general anesthesia. Additional local anesthesia injection just after or during the operation was performed in 15 patients as nine in CS and six in HS groups. The mean operation time for the conventional group was $22.9 \pm 5.2$ and $17.8 \pm 5.2$ minutes for the harmonic scalpel group $(\mathrm{p}=0.001)$. The mean hospitalization times for $\mathrm{CH}$ and $\mathrm{HS}$ groups were $1.3 \pm 0.5$ and $1.2 \pm 0.4$ days, respectively $(\mathrm{p}=0.155)$. There were significant differences between the two groups in regard to analgesic requirement and operation times $(\mathrm{p}=0.038$ and $\mathrm{p}=0.001$, respectively).

Sixty patients in the conventional diathermy group were analyzed for additional need of analgesics. 45 (75\%) patients were found to have been given additional dose of analgesics, and their subjective pain score was 5 . Ten (17\%) patients scored as 4 and only $5(8 \%)$ patients took the score of 3 considering postoperative pain. Of the 53 patients in the harmonic scalpel group, $30(56 \%)$ needed extra analgesic use and 35(66\%) patients' subjective pain score was 5 . Ten (19\%) patients scored as 4 and $8(15 \%)$ patients took a score of 3 . The difference was significant for extra analgesic use $(\mathrm{p}=0.038)$ but not for pain perception $(p=0.294)$ even though the HS group had significantly lower extra analgesic requirement.

There were two patients $(3.3 \%)$ with bleeding that needed to be intervened in $\mathrm{CH}$ Group, and one (1.8\%) in HS Group (Table 2). They were treated medically with simple packing and observation. Only one patient in $\mathrm{CH}$ Group needed additional simple suturing in the early postoperative period. The other bleedings in both groups occurred after 72 hours postoperatively and they were treated medically with simple packing and observation. Urinary retention was encountered in four $(6.6 \%)$ and three patients $(5.6 \%)$ in $\mathrm{CH}$ and $\mathrm{HS}$ Groups, respectively (Table 2). None of the patients with general anesthesia had urinary retention. As for other complications, we did not encounter any incontinence in both groups. During the follow up period, there were no late complications such as recurrence or anal stenosis.

Table 1: Demographic data and features of the treatment modalities.

\begin{tabular}{l|ccc} 
& CH Group & HS Group & \\
& $(\mathrm{n}=60)$ & $(\mathrm{n}=53)$ & $\mathrm{p}$ \\
\hline Age $($ years $)$ & $45.3 \pm 11.8$ & $45.7 \pm 12.7$ & 0.846 \\
Gender $($ female/male) & 23.3 & 22.7 & 0.933 \\
BMI $\left(\mathrm{kg} / \mathrm{m}^{2}\right)$ & $25.8 \pm 5.4$ & $24.1 \pm 6$ & 0.125 \\
Operation time (min) & $22.9 \pm 5.2$ & $17.9 \pm 5.3$ & 0.001 \\
Pain score $>5$ & $45(75 \%)$ & $35(67 \%)$ & 0.294 \\
Analgesic requirement (number) & $45(75 \%)$ & $30(56 \%)$ & 0.038 \\
Length of hospitalization (day) & $1.3 \pm 0.5$ & $1.17 \pm 0.4$ & 0.155
\end{tabular}

Table 2: The complications and their respective rates.

\begin{tabular}{l|cc} 
& CH group & HS group \\
\hline Bleeding & $2(3.3 \%)$ & $1(1.8 \%)$ \\
Urinary retention & $4(6.6 \%)$ & $3(5.6 \%)$
\end{tabular}

\section{Discussion}

Surgery is the gold standard for advanced stage hemorrhoidal disease. However, conventional hemorrhoidectomy (both open and closed) is associated with significant postoperative pain, irritation, and discharge. The postoperative pain may lead to urinary retention and constipation. Therefore, there are always attempts to find an easy to perform operation with less postoperative pain. HS both cuts and seals simultaneously and makes little thermal damage (1-3 mm). Harmonic devices perform simultaneous ultrasonic cutting and coagulation by mechanical vibration and provide hemostasis at a lower temperature than electrosurgical devices [7]. Ideally, both internal and external hemorrhoidal packages must be removed completely with minimal postoperative pain. The operation must be easy and short to perform. It must have the least complications as well as recurrence [8].

Excisional hemorrhoidectomy is the gold standard operation for grade 3-4 hemorrhoidal diease and complicated hemorrhoids. Closed (Ferguson) hemorrhoidectomy is found to be superior to open hemorrhoidectomy when the patient comfort and continence is considered [9]. However, both procedures have been found to be equally effective and safe [10]. The grave problem about the conventional hemorrhoidectomies is the postoperative pain starting just after the operation and still exists as a major issue, even though the procedure is considered to be an old intervention. This aspect has been analyzed in several studies, as the hemorrhoidectomy is a procedure in which the severe pain necessitating opioid drugs in analgesic management occurs in $20-40 \%$ of patients $[11,12]$.

In a double blind randomized study, Chung et al [13] found that HS hemorrhoidectomy had the best pain score when compared with hemorrhoidectomes with bipolar scissors and Milligan-Morgan hemorrhoidectomy, and that patients required significantly less pethidine injection after HS hemorrhoidectomy than it was in Milligan-Morgan hemorrhoidectomy. In another study by Armstrong et al [14], HS hemorrhoidectomy group had significantly less pain than the electrocautery patients had, on each postoperative day. Analgesic needs were also significantly less in the HS group on days 1, 2, 7, and 14. There was no correlation between the postoperative pain and the grade of hemorrhoids, the status of the surgical incision as in either open or closed. Bleeding is an important complication of hemorrhoidectomy which may be fatal, when accompanied by other medical conditions [15]. Early postoperative hemorrhage is defined as immediate bleeding which happens within the early postoperative period from 24 to 48 hours and is likely related to the loss of control of the vascular pedicle. Delayed bleeding is defined as a hemorrhage reported up to 2 weeks postoperatively, and is more often related to infection or local trauma [16]. Considering the bleeding rates in the present study, it was in agreement with the literature even though the definition of hemorrhage differs. Late hemorrhage occurred in a series of HS hemorrhoidectomies as $1.7 \%$ [17]. This is in agreement with the rate of around $2 \%$ that is reported in the literature [16]. The hemorrhage rates were given as $5 \%$ for the open technique and 9 $\%$ for the closed in a study by Ho et al [18]. However, these rates were given by Neto et al [19], as 0 percent and $0.6 \%$, respectively.

Ninety percent of anal stenosis is caused by overzealous hemorrhoidectomy. Excision of large areas of anoderm and hemorrhoidal rectal mucosa, without sparing of adequate mucocutaneous bridges, leads to scarring and a progressive chronic stricture. However, it is a rare complication after the introduction of Milligan-Morgan procedure. Likewise, we didn't encounter any reported anal stenosis.

We did not encounter any anal incontinence in both groups. This is because of mostly anal continence is becoming rare and rare as hemorrhoidectomy is considered to be an old operation nowadays. However, in our study the return time to work could not be studied. Abo Hasem et al [20] noticed a 
significant difference in the time needed to return to work in favor to the HS method than the conventional one. Seventy-five percent of the patients in HS Group reported full-time return to work within the first two weeks postoperatively while for $\mathrm{CH}$ Group, this was true only for forty-five percent of the patients [20]. In another study of Chung et al [13], it was reported that return to work or normal activity for Milligan-Morgan and electrothermy and HS was different from each other. The period was shorter in the HS group, but this was not significantly different [13].

The operation time was significantly shorter in HS Group when compared to $\mathrm{CH}$ Group. This may be due to the technique applied by HS because of the shape and design of the device, since it can seal and cut longer measures of tissues in a shorter period of time. In a small group, Tan et al [21] found no significant difference in the operation time between two groups with a similar mean operating time for both groups. Khan et al [22] found the mean operative time for closed hemorrhoidectomy with electrocautery as $35.7 \pm 3$ minutes; for HS patients, it was $31.7 \pm 2$ minutes. There was no statistical difference even though it was shorter on the average for HS Group. Our findings were consistent with the findings of Ramadan et al [23] in which they reported the operation times as $29.6 \pm 5.4$ vs $13.2 \pm 1.7$ minutes, which was significantly shorter for the HS group. Another study from Turkey revealed much shorter time for HS, where Ozer et al [24] found 45 minutes for $\mathrm{CH}$ vs 20 minutes for HS groups.

There were no significant differences in the hospital stay because in our study group even though most of our patients were discharged on the first day after the surgery. Delayed hospital stay in our group was because of prolonged pain and the need of analgesics almost all the time except one patient for prolonged urinary retention in the $\mathrm{CH}$ group. Chung et al [13] found no significant difference in the hospital stay for two groups which were 3.8 vs 3.1 days for $\mathrm{CH}$ and $\mathrm{HS}$, respectively. Ramadan et al [23] found the hospitalization duration as 40.6 vs 21 hours for $\mathrm{CH}$ vs $\mathrm{HS}$ in an outpatient series, respectively. Although there are outpatient clinics which perform both conventional hemorrhoidectomy and other methods, we think that postoperative pain relief plays an important role for patient comfort. We think that by reducing the operation time and postoperative pain, HS hemorrhoidectomy, unlike $\mathrm{CH}$, may be an ideal operation for such outpatient clinics. We noticed a small group of patients who has lower postoperative pain scores and less indication of additional analgesics. This group of 15 patients ( 9 in CS and 6 in HS) had the additional local anesthesia injection just after or during the operation. This was done by individual basis mostly on complicated hemorrhoids and both internal and external large packages. This small group was included in overall analysis since they constituted a tiny percent of the patients. This inspires and encourages us in the use of local anesthetics after the operation, even though we have not tried this observation in a double blind prospective study. We are further encouraged by the studies published previously. For example, in a double blind study, the investigators compared ropivacaine to saline injection and they found that local infiltration with ropivacaine improved immediate postoperative pain control after hemorrhoidal surgery [25]. In a meta-analysis about post hemorrhoidectomy pain relief, Joshi et al [12] found that local anesthetic injection, either as a sole technique or as an adjunct to general or regional anesthesia are recommended, therefore, long-acting local anesthetics are recommended for all patients undergoing hemorrhoidal surgery. In a prospective study by Bansal et al [26] comparing local anesthesia with bupivacain/xylocaine with spinal anesthesia, they found out that postoperative analgesia had very excellent removal of postoperative pain seen in more than $90 \%$ of the patients operated on under local anesthesia, while it was achieved in less than $50 \%$ of the patients operated on under spinal anesthesia $(\mathrm{p}<0.05)$. Additionally, they found that certain postoperative complications such as urinary retention and postoperative headache were always seen in the spinal anesthesia group [26].

The patients were questioned about involuntary leakage of flatus or stool and would be referred to anal manometry to evaluate anal incontinence. We did not encounter any anal incontinence in both groups based on the questioning. This is because of mostly anal continence is becoming rare and rare as hemorrhoidectomy is considered an old operation nowadays.

There are weak points in our study because of retrospective data collection, which resulted in loss of valuable data such as information of return to work of patients. Besides, the surgical interventions were not carried out by the same surgeon; therefore, we cannot be definite about the operation time difference between these two procedures. However, that disadvantage was softened by standardization of the surgical techniques, since our hospital serves as a big community in a city of 15 million of population, in addition to being a training center and consists of two large surgical departments working under supervision of one directory management both in patients' selection and correct grading of hemorrhoids. Therefore, the surgeons may have really very little individual variances in regard to their techniques, since there is a strong consensus over the surgical policy on hemorrhoids, which had standardized the surgical techniques and hindered unnecessary hemorrhoidectomies in the series. Hence the series constituted of only large hemorrhoids, because we all believe in preserving hemorrhoids to help continence and prevent chronic postoperative itching due to chronic postoperative anal fluid leakage. Even though the study was not a randomized one, clear information about the benefits of HS hemorrhoidectomy and the usage of local anesthesia to relieve pain in the early postoperative period has been gathered from the findings of the study.

In conclusion, hemorrhoidectomy using $\mathrm{HS}$ is advantageous and superior to conventional diathermy hemorrhoidectomy in regard to shorter operation time and earlier discharge from the hospital with no additional complications added.

\section{References}

1. Riss S, Weiser FA, Schwameis K, Riss T, Mittlböck M, Steiner G, et al. The prevalence of hemorrhoids in adults. Int $\mathrm{J}$ Colorectal Dis. 2012;27:215-20.

2. Johanson JF, Sonnenberg A. The prevalence of hemorrhoids and chronic constipation. An epidemiologic study. Gastroenterology. 1990;98:380-6

3. Morgado PJ, Suárez JA, Gómez LG, Morgado PJ. Histoclinical basis for a new classification of hemorrhoidal disease. Dis Colon Rectum. 1988;31:474-80.

4. Brown SR. Haemorrhoids: an update on management. Ther Adv Chronic Dis. 2017;8:141-7.

5. Lee KC, Chen HH, Chung KC, Hu WH, Chang CL, Lin SE, et al. Meta-analysis of randomized controlled trials comparing outcomes for stapled hemorrhoidopexy versus LigaSure hemorrhoidectomy for symptomatic hemorrhoids in adults. Int J Surg. 2013;11:914-8.

6. Lim DR, Cho DH, Lee JH, Moon JH. Comparison of a hemorrhoidectomy with ultrasonic scalpel versus a conventional hemorrhoidectomy. Ann Coloproctol. 2016;32:111-6.

7. Carlander J, Johansson K, Lindström S, Velin AK, Jiang CH, Nordborg C. Comparison of experimental nerve injury caused by ultrasonically activated scalpel and electrosurgery. $\mathrm{Br} \mathrm{J}$ Surg. 2005;92:772-7.

8. Lohsiriwat V. Treatment of hemorrhoids: A coloproctologist's view. World J Gastroenterol. 2015;21:9245-52.

9. Johannsson HO, Pahlman L, Graf W. Randomized clinical trial of the effects on anal function of Milligan-Morgan versus Ferguson haemorrhoidectomy. Br J Surg. 2006;93:1208-14. 
10. Arbman G, Krook H, Haapaniemi S. Closed vs. open hemorrhoidectomy--is there any difference? Dis Colon Rectum. 2000;43:31-4.

11. Gerbershagen HJ, Aduckathil S, van Wijck AJ, Peelen LM, Kalkman CJ, Meissner W. Pain intensity on the first day after surgery: a prospective cohort study comparing 179 surgical procedures. Anesthesiology. 2013;118:934-44.

12. Joshi GP, Neugebauer EA, Bonnet F, Camu F, Fischer HB, Rawal N. Evidence-based management of pain after haemorrhoidectomy surgery. Br J Surg. 2010;97:1155-68.

13. Chung CC, Ha JP, Tai YP, Tsang WW, Li MK. Doubleblind, randomized trial comparing harmonic scalpel hemorrhoidectomy, bipolar scissors hemorrhoidectomy, and scissors excision: ligation technique. Dis Colon Rectum. 2002;45:789-94.

14. Armstrong DN, Ambroze WL, Schertzer ME, Orangio GR. Harmonic Scalpel vs. hemorrhoidectomy: a prospective evaluation. Dis Colon Rectum. 2001;44:558-64.

15. Jensen $C$, Jørgensen $H$. Late, life-threatening bleeding after hemorrhoidectomy. Ugeskr Laeger. 2001;163:41-2.

16. Kunitake H, Poylin V. Complications following anorectal surgery. Clin Colon Rectal Surg. 2016;29:14-21.

17. Haveran LA, Sturrock PR, Sun MY, McDade J, Singla S, Paterson CA, et al. Simple harmonic scalpel hemorrhoidectomy utilizing local anesthesia combined with intravenous sedation: a safe and rapid alternative to conventional hemorrhoidectomy. Int $\mathbf{J}$ Colorectal Dis. 2007;22:801-6

18. Ho YH, Seow-Choen F, Tan M, Leong AF. Randomized controlled trial of open and closed haemorrhoidectomy. Br J Surg. 1997;84:172930.

19. Neto JA, Quilici FA, Cordeiro F, Reis JA. Open versus semi-open hemorrhoidectomy: a random trial. Int Surg. 1992;77:84-90.

20. Abo-hashem AA, Sarhan A, Aly AM. Harmonic scalpel compared with bipolar electro-cautery hemorrhoidectomy: a randomized controlled trial. Int J Surg. 2010;8:243-7.

21. Tan JJ, Seow-Choen F. Prospective randomized trial comparing diathermy and harmonic scalpel hemorrhoidectomy. Dis Colon Rectum. 2001;44:677-9.

22. Khan S, Pawlak SE, Eggenberger JC, Lee CS, Szilagy EJ, Wu JS, et al. Surgical treatment of hemorrhoids: prospective, randomized trial comparing closed excisional hemorrhoidectomy and the harmonic scalpel technique of excisional hemorrhoidectomy. Dis Colon Rectum. 2001;44:845-9.

23. Ramadan E, Vishne T, Dreznik Z. Harmonic scalpel hemorrhoidectomy: preliminary results of a new alternative method. Tech Coloproctol. 2002;6:89-92.

24. Ozer MT, Yigit T, Uzar AI, Mentes O, Harlak A, Kilic S, et al. A comparison of different hemorrhoidectomy procedures. Saudi Med J. 2008;29:1264-9.

25. Vinson-Bonnet B, Coltat JC, Fingerhut A, Bonnet F. Local infiltration with ropivacaine improves immediate postoperative pain control after hemorrhoidal surgery. Dis Colon Rectum. 2002;45:104-8.

26. Bansal H, Jenaw RK, Mandia R, Yadav R. How to do Open Hemorrhoidectomy Under Local Anesthesia and its Comparison with Spinal Anesthesia. Indian J Surg. 2012;74:330-3. 